Acta Agroph., 2018, 25(4), 421-435

doi: $10.31545 /$

\title{
A STUDY ON THE TWIN SCREW EXTRUSION-COOKING OF PLANT-MEAT PET FOOD MIXTURES
}

\author{
Aldona Sobota, Piotr Zarzycki, Emilia Sykut-Domańska, Anna Wirkijowska, \\ Zbigniew Rzedzicki, Agnieszka Pawlas
}

Division of Engineering and Cereals Technology, Department of Plant Food Technology and Gastronomy University of Life Sciences in Lublin

ul. Skromna 8, 20-704 Lublin, Poland

e-mail: piotr.zarzycki@up.lublin.pl

\begin{abstract}
A study was conducted on the possibility of application of "dry" extrusion-cooking technology for the processing of plant-meat mixtures. The effect of the concentration of the meat material (meat-bone pulp), leguminous material (faba bean), wheat grain meal and extrusion temperature on the process run, physicochemical properties and on the microstructure of the extrudates was investigated. It was demonstrated that extrusion-cooking with a twin-screw extruder permits the processing of blends with up to $30 \%$ meat-bone pulp content. Increase in the content of the meat material caused a decrease of specific density and water solubility index (WSI) of the extrudates. At the same time, a significant increase in the content of proteins, fat, and ash was observed. Extrusion temperature increase from 130 to $250^{\circ} \mathrm{C}$ caused an increase in the degree of expansion ratio and impact strength of the extrudates and a decrease in specific density of the products. At the same time, the microstructure of the products was changed from cohesive and compacted to more expanded and porous.

Keywords: extrusion-cooking, faba been, meat-bone pulp, pet food, wheat
\end{abstract}

\section{INTRODUCTION}

Extrusion processing has become very popular in the feed and food industries due to its high versatility, productivity, and product quality (Guz et al. 2011, Ayadi et al. 2012, Samuelsen et al. 2013, Guz et al. 2014, Oniszczuk et al. 2017). During the extrusion process, as a result of high temperature, pressure and shear forces, the material processed is intensively mixed, compressed and plasticised, inclusive of the liquefaction of the mass due to phase transition. At the time of liquefaction the material is cooked and forced under pressure through the die of the extruder (Castells et al. 2005). Such treatment permits physicochemical transformation of 
the material; gelatinisation of starch, denaturation of protein, inactivation of some anti-nutritional factors, and the obtainment of a product with very high microbiological purity. It has been demonstrated that the process of extrusion leads to a reduction of the total number of microorganisms (Okelo et al. 2006) and spores of bacteria (Likimani and Sofos 1990). Van de Velde et al. (1984), using the most thermo-resistant strains of bacteria (Bacillus stearothermophilus FS 1518), demonstrated that twin-screw extrusion guarantees sterility of the extrudate if - for a given temperature - a minimum time of the material retention in the extruder is guaranteed. It needs to be noted, however, that only strict control of the time of material retention in the extruder and assurance of appropriate extrusion temperature provides a guarantee of sterility of the product. Fulfilment of those conditions is possible only in the case of counter-rotating twin-screw extrusion.

The physical properties of the extrudate, e.g. porosity structure, texture, expansion, specific density, water solubility index (WSI), play a significant role in the case of pet food. These properties can be created through the composition of the blend material as well as the parameters of the extrusion process, such as the profile of barrel temperature, pressure distribution, configuration and speed of the extruder screws, size and shape of the die (Sobota and Rzedzicki 2009, Ayadi et al. 2012, Samuelsen et al. 2013, Wójtowicz et al. 2015).

The aim of the study was to investigate the applicability of meat-bone pulp for the production of pet food using the counter-rotating twin-screw extrusion process. The influence of the raw material composition (concentration of meat-bone pulp and faba bean meal) and of the process temperature on the physical properties, chemical composition and microstructure of the products was analysed.

\section{MATERIALS AND METHODS}

Meat-bone pulp (MBP) from mechanical de-boning of poultry carcasses (Indykpol S.A., Lublin, Poland), faba bean meal (FBM) (Vicia Faba L. cv. Nadwiślański) (Agropol, Motycz, Poland) and wheat grain meal (WGM) (Triticum aestivum L. cv. Henika) (Agropol, Motycz, Poland) were used in this study. The chemical composition of these materials is presented in Table 1.

The plant materials were fragmented in an impact grinder type H-111/3 (Agromet, Jawor, Poland), using a sieve with a hole diameter of $3 \mathrm{~mm}$. The meat component was mixed with the plant materials in a periodic mixer type H-095 (Agro-Wikt, Opoczno, Poland) with capacity of $80 \mathrm{dm}^{3}$.

The study was conducted using a counter-rotating twin-screw extruder (Metalchem, Gliwice, Poland) with conical screws, with L:D ratio of 12:1 and with 3 open forming dies, each $6 \mathrm{~mm}$ in diameter. The screw speed applied was $75 \mathrm{rpm}$. 
Table 1. Chemical composition of raw materials

\begin{tabular}{lccc}
\hline \multicolumn{1}{c}{ Nutrient } & Meat-bone pulp & Wheat grain meal & Faba bean meal \\
\hline Dry matter (\%) & 43.96 & 87.17 & 89.97 \\
Crude protein (\% d.w.) & 43.25 & 17.21 & 29.87 \\
Crude fat (\% d.w.) & 19.98 & 1.45 & 0.90 \\
Ash (\% d.w.) & 33.15 & 2.33 & 4.51 \\
TDF (\% d.w.) & - & 21.31 & 35.00 \\
IDF (\% d.w.) & - & 17.54 & 29.22 \\
SDF (\% d.w.) & - & 3.77 & 5.78 \\
\hline
\end{tabular}

TDF - total dietary fibre, IDF - insoluble dietary fibre; SDF - soluble dietary fibre; d.w. - dry weight

The model of the experiment is presented in Table 2. In the first part of the experiment, the share of the meat-bone pulp varied in the range of 5 to $30 \%$ (samples 1-6). At the same time, a constant ratio (1:4) between faba bean meal and wheat grain meal was used. In the second part of the experiment, the share of faba bean was variable (between 0 and 30\%, samples 7-13) and a constant ratio of meat-bone pulp $(20 \%)$ was used. In the third part of the work, the blends composition was constant while the temperature of extrusion was varied between 130 and $250^{\circ} \mathrm{C}$ (samples 14-20). The parameter ranges applied in the study and the composition of the blend were determined on the basis of pilot experiments. Only such parameters were adopted that guaranteed correct and stable run of the process.

Table 2. Model of experiment

\begin{tabular}{lcccc}
\hline \multirow{2}{*}{ Sample } & \multicolumn{3}{c}{ Components $(\%)$} & $\begin{array}{c}\text { Profile of barrel temperature } \\
\left({ }^{\circ} \mathrm{C}\right)\end{array}$ \\
\cline { 2 - 4 } 1 & Meat-bone pulp & Faba bean meal & Wheat grain meal & \\
2 & 5 & 19 & 76 & \\
3 & 10 & 18 & 72 & $120 / 140 / 180 / 180 / 130$ \\
4 & 15 & 17 & 68 & \\
5 & 20 & 16 & 64 & \\
6 & 25 & 15 & 60 & \\
\hline 7 & 30 & 14 & 56 & $120 / 140 / 180 / 180 / 130$ \\
8 & 20 & 0 & 80 & \\
9 & 20 & 5 & 75 & \\
10 & 20 & 10 & 70 & $110 / 130 / 150 / 150 / 130$ \\
11 & 20 & 15 & 65 & $120 / 140 / 170 / 170 / 130$ \\
12 & 20 & 20 & 60 & $125 / 150 / 190 / 190 / 130$ \\
13 & 20 & 25 & 55 & $130 / 160 / 210 / 210 / 130$ \\
14 & 20 & 30 & 50 & $140 / 170 / 230 / 230 / 130$ \\
15 & & & & $150 / 180 / 250 / 250 / 130$ \\
16 & & & & \\
17 & 20 & 20 & & \\
18 & & & & \\
19 & & & & \\
20 & & & & \\
\hline
\end{tabular}


To maintain constant and comparable conditions of extrusion, samples with a lower content of the meat component were moistened to the moisture content of $28 \%$. That moisture level permitted the process of "dry" extrusion, and at the same time contributed to the maintenance of high nutritional value of the extrudates.

Expansion ratio was calculated as the ratio of the cross section area of the extrudates to the cross section area of the die. Specific density was calculated from the ratio of the mass to the volume of the samples tested (Rzedzicki et al. 2000). Measurements of impact strength were made with the use of the Charpy impact test. Charpy hammer (Wolfgang Ohst, Rathenow, Germany) with supports spacing of $40 \mathrm{~mm}$ and hammer of $0.5 \mathrm{~J}$ was used. The water solubility index (WSI) was assayed according to the centrifuge method (AACC, 88-04) modified by the authors. Ground sample $(2 \mathrm{~g})$ was placed in centrifuge tubes, $30 \mathrm{ml}$ of distilled water was added, then the tubes were stopped and shaken vigorously. The suspension was left to rest for 5 minutes, then it was centrifuged for $15 \mathrm{~min}$ at $2200 \mathrm{~g} .10 \mathrm{ml}$ of the supernatant was dried to solid mass.

$W S I(\%)=\left(\right.$ weight of dried supernatant $\frac{30 \mathrm{ml}}{10 \mathrm{ml}} /$ dry weight of sample $) 100 \%$

Moisture content (MC) was determined with the method AACC 44-15A. Dry matter $(\mathrm{DM})$ content was calculated from the formula: $100 \%-\mathrm{MC}(\%)=\mathrm{DM}(\%)$. Ash content was assayed according to the method AACC 08-01, protein content with the method AACC 46-08, using nitrogen to protein conversion factor of $\mathrm{N} x$ 6.25. For protein content analysis the Kjeltec ${ }^{\mathrm{TM}} 2300$ Automatic Analyzer (Foss, Hoganas, Sweden) was used. Free fat was determined in accordance with the method AACC 30-26 (AACC, 2000) by means of Soxtec ${ }^{\mathrm{TM}} 2050$ (Foss, Hoganas, Sweden). Enzymatic method was applied to determine the content of total dietary fibre (TDF), insoluble dietary fibre (IDF) and soluble dietary fibre (SDF). In the enzymatic fibre determinations, Megazyme enzymes and procedures were employed (AOAC 991.43; AACC 32-07; AACC 32-21; AOAC 985.29; AACC 32-05). The content of minerals - calcium, magnesium, sodium, potassium, manganese, copper, iron, zinc, chromium and nickel - in the extrudates was assayed with the method AOAC 975.03 (AOAC, 1990).

Changes in the microstructure of the extrudates were analysed as a function of the increasing proportion of faba bean and process temperature. Samples were used to slice off fragments of extrudates that were then glued with silver paste onto specimen circles, and sprayed with carbon and gold in a vacuum sprayer type JEE 4X (JEOL, Tokyo, Japan). Microscope analyses were made with the help of electron microscope type JSM 5200 (JEOL, Tokyo, Japan).

Chemical analyses were made in three replicates. Physical properties were analysed in five replicates. Mean values, standard deviations, and significance of differences between mean values (Duncan test, $\mathrm{P} \leq 0.05$ ) were determined. Backward 
stepwise regression procedure, in which the choice of predictive variables was carried out by an automatic procedure, was used to build regression models $(\alpha=0.05)$. The dependent variables for which regression models were built were expansion ratio, specific density, impact strength, WSI, crude protein, crude fat, ash and TDF. The predictor variables were extrusion temperature, meat-bone pulp and faba bean meal content. Statistical analysis of the results was performed with the use of the program SAS 9.1.3 (SAS Institute Inc., Cary, USA).

\section{RESULTS}

\section{Effect of the concentration of meat-bone pulp (MBP)}

Extrudates with a content of MBP had a compact and hard structure, resistant to crumbling. Increase of the content of MBP in the extrudates caused an increase of radial expansion and impact strength. At the same time, a decrease in the specific density of the products was observed (Tab. 3). The index of dry matter solubility (WSI) was low and fell within the range from 5.51 to $8.92 \%$ (Tab. 3). Increase in the content of the meat component caused a significant drop (Duncan test, $\mathrm{P} \leq 0.05$ ) in the values of WSI.

Table 3. Physical properties of the extrudates

\begin{tabular}{lcccc}
\hline Sample & Expansion ratio & $\begin{array}{c}\text { Specific density } \\
\left(\mathrm{kg} \mathrm{m}^{-3}\right)\end{array}$ & $\begin{array}{c}\text { Impact strength } \\
\left(\mathrm{J} \mathrm{cm}^{-2}\right)\end{array}$ & $\begin{array}{c}\text { WSI } \\
(\% \mathrm{~d} . \mathrm{w} .)\end{array}$ \\
\hline 1 & $1.79^{\mathrm{g}} \pm 0.03$ & $988.78^{\mathrm{a}} \pm 3.12$ & $0.058^{\mathrm{j}} \pm 0.001$ & $8.92^{\mathrm{a}} \pm 0.38$ \\
2 & $1.85^{\mathrm{f}} \pm 0.04$ & $982.26^{\mathrm{b}} \pm 2.02$ & $0.061^{\mathrm{j}} \pm 0.001$ & $7.16^{\mathrm{b}} \pm 0.02$ \\
3 & $1.98^{\mathrm{e}} \pm 0.02$ & $937.53^{\mathrm{e}} \pm 1.03$ & $0.072^{\mathrm{g}} \pm 0.002$ & $7.05^{\mathrm{bc}} \pm 0.04$ \\
4 & $1.98^{\mathrm{e}} \pm 0.02$ & $934.34^{\mathrm{f}} \pm 1.31$ & $0.067^{\mathrm{ih}} \pm 0.001$ & $6.14^{\mathrm{h}} \pm 0.07$ \\
5 & $2.00^{\text {ed }} \pm 0.03$ & $883.51^{\mathrm{m}} \pm 1.93$ & $0.077^{\mathrm{f}} \pm 0.003$ & $5.80^{\mathrm{i}} \pm 0.39$ \\
6 & $1.99^{\text {ed }} \pm 0.03$ & $900.42^{\mathrm{k}} \pm 2.12$ & $0.08^{\mathrm{fe}} \pm 0.001$ & $5.51^{\mathrm{j}} \pm 0.26$ \\
\hline 7 & $2.07^{\mathrm{cba}} \pm 0.03$ & $848.28^{\mathrm{n}} \pm 1.51$ & $0.052^{\mathrm{k}} \pm 0.004$ & $6.41^{\mathrm{gf}} \pm 0.01$ \\
8 & $2.05^{\mathrm{dcba}} \pm 0.04$ & $889.27^{\mathrm{l}} \pm 1.58$ & $0.06^{\mathrm{j}} \pm 0.001$ & $6.53^{\mathrm{fe}} \pm 0.02$ \\
9 & $2.04^{\text {edcb }} \pm 0.02$ & $915.48^{\mathrm{i}} \pm 0.97$ & $0.07^{\mathrm{hg}} \pm 0.002$ & $6.43^{\mathrm{gf}} \pm 0.18$ \\
10 & $2.03^{\text {edc }} \pm 0.02$ & $924.59^{\mathrm{h}} \pm 1.17$ & $0.065^{\mathrm{i}} \pm 0.001$ & $6.31^{\mathrm{hgf}} \pm 0.02$ \\
11 & $2.04^{\mathrm{edcb}} \pm 0.03$ & $916.41^{\mathrm{i}} \pm 0.85$ & $0.085^{\mathrm{cb}} \pm 0.002$ & $6.33^{\mathrm{hgf}} \pm 0.05$ \\
12 & $2.04^{\mathrm{edcb}} \pm 0.02$ & $915.84^{\mathrm{i}} \pm 1.58$ & $0.084^{\mathrm{dcb}} \pm 0.001$ & $6.85^{\mathrm{dc}} \pm 0.04$ \\
13 & $2.04^{\text {edcb }} \pm 0.02$ & $908.78^{\mathrm{j}} \pm 1.05$ & $0.096^{\mathrm{a}} \pm 0.003$ & $6.34^{\mathrm{hgf}} \pm 0.05$ \\
\hline 14 & $1.52^{\mathrm{h}} \pm 0.01$ & $987.57^{\mathrm{a}} \pm 0.72$ & $0.053^{\mathrm{k}} \pm 0.002$ & $6.40^{\mathrm{hgf}} \pm 0.05$ \\
15 & $1.78^{\mathrm{g}} \pm 0.02$ & $950.48^{\mathrm{d}} \pm 1.23$ & $0.061^{\mathrm{j}} \pm 0.003$ & $6.77^{\mathrm{ed}} \pm 0.01$ \\
16 & $1.90^{\mathrm{f}} \pm 0.03$ & $953.9^{\mathrm{c}} \pm 2.01$ & $0.081^{\mathrm{de}} \pm 0.004$ & $6.56^{\mathrm{fe}} \pm 0.1$ \\
17 & $2.04^{\mathrm{edcb}} \pm 0.03$ & $949.28^{\mathrm{d}} \pm 0.97$ & $0.087^{\mathrm{b}} \pm 0.001$ & $6.58^{\mathrm{fe}} \pm 0.09$ \\
18 & $2.08^{\mathrm{cba}} \pm 0.04$ & $931.43^{\mathrm{g}} \pm 1.56$ & $0.082^{\mathrm{edc}} \pm 0.001$ & $6.55^{\mathrm{fe}} \pm 0.06$ \\
19 & $2.11^{\mathrm{a}} \pm 0.02$ & $899.97^{\mathrm{k}} \pm 1.02$ & $0.077^{\mathrm{f}} \pm 0.002$ & $6.21^{\mathrm{hg}} \pm 0.03$ \\
20 & $2.10^{\mathrm{ba}} \pm 0.04$ & $901.93^{\mathrm{k}} \pm 0.91$ & $0.073^{\mathrm{g}} \pm 0.001$ & $6.43^{\mathrm{gf}} \pm 0.04$ \\
\hline
\end{tabular}

WSI - water solubility index; $\mathrm{a}-\mathrm{n}-$ means within in a column with different letters differ at $\mathrm{P} \leq 0.05$; d.w. - dry weight 
The addition of MBP to the wheat-faba bean blend caused also significant changes in the chemical composition of the extrudates. A significant increase was noted in the content of protein, fat and ash. Sample with $30 \%$ addition of the meat-bone pulp was characterised by $21.96 \%$ d.w. content of protein, $4.02 \%$ d.w. content of crude fat and $4.57 \%$ d.w. content of ash. The dietary fibre content (TDF), including soluble (SDF) and insoluble fractions (IDF), decreased with the addition of MBP (Tab. 4).

Table 4. Chemical composition of the extrudates

\begin{tabular}{|c|c|c|c|c|c|c|c|}
\hline \multirow{2}{*}{ Sample } & Dry matter & Crude protein & Crude fat & Ash & TDF & SDF & IDF \\
\hline & $(\%)$ & \multicolumn{6}{|c|}{ (\% d.w.) } \\
\hline 1 & $91.16^{\mathrm{gh}} \pm 0.03$ & $18.79^{j} \pm 0.04$ & $1.57^{\mathrm{i}} \pm 0.02$ & $3.26^{\mathrm{n}} \pm 0.01$ & $21.46^{\mathrm{e}} \pm 0.13$ & $5.16^{\mathrm{d}} \pm 0.06$ & $16.3^{\mathrm{i}} \pm 0.09$ \\
\hline 2 & $91.13^{\mathrm{h}} \pm 0.06$ & $19.47^{\mathrm{h}} \pm 0.05$ & $1.96^{\mathrm{h}} \pm 0.04$ & $4.07^{\mathrm{m}} \pm 0.02$ & $21.64^{\mathrm{e}} \pm 0.12$ & $5.05^{\mathrm{ef}} \pm 0.05$ & $16.59^{\mathrm{h}} \pm 0.07$ \\
\hline 3 & $91.73^{\mathrm{d}} \pm 0.05$ & $20.38^{\mathrm{f}} \pm 0.49$ & $2.33^{\mathrm{fg}} \pm 0.09$ & $5.01^{1} \pm 0.03$ & $20.92^{\mathrm{g}} \pm 0.04$ & $4.88^{\mathrm{g}} \pm 0.02$ & $16.04^{j} \pm 0.06$ \\
\hline 4 & $92.36^{\mathrm{a}} \pm 0.04$ & $20.61^{\mathrm{e}} \pm 0.07$ & $2.81^{\mathrm{bcd}_{ \pm}} 0.06$ & $5.84^{\mathrm{ij}} \pm 0.04$ & $20.05^{\mathrm{i}} \pm 0.1$ & $4.73^{\mathrm{hij}} \pm 0.03$ & $15.32^{\mathrm{k}} \pm 0.07$ \\
\hline 5 & $91.18^{\mathrm{fgh}} \pm 0.16$ & $21.34^{\mathrm{cd}} \pm 0.06$ & $3.07^{b} \pm 0.67$ & $6.63^{\mathrm{b}} \pm 0.07$ & $19.12^{\mathrm{k}} \pm 0.14$ & $4.48^{\mathrm{k}} \pm 0.04$ & $14.64^{1} \pm 0.1$ \\
\hline 6 & $91.21^{\mathrm{fgh}} \pm 0.06$ & $21.96^{\mathrm{b}} \pm 0.07$ & $4.02^{\mathrm{a}} \pm 0.1$ & $7.57^{\mathrm{a}} \pm 0.06$ & $17.52^{\mathrm{m}} \pm 0.03$ & $3.84^{1} \pm 0.03$ & $13.68^{\circ} \pm 0.06$ \\
\hline 7 & $91.26^{\mathrm{fgh}} \pm 0.07$ & $19.12^{\mathrm{i}} \pm 0.07$ & $2.96^{\mathrm{bc}} \pm 0.08$ & $5.67^{\mathrm{k}} \pm 0.02$ & $18.58^{1} \pm 0.1$ & $4.65^{\mathrm{ij}} \pm 0.07$ & $13.93^{\mathrm{n}} \pm 0.03$ \\
\hline 8 & $92.31^{\mathrm{a}} \pm 0.06$ & $19.57^{\mathrm{h}} \pm 0.07$ & $2.84^{\mathrm{bcd}} \pm 0.09$ & $5.79^{\mathrm{j}} \pm 0.01$ & $19.12^{\mathrm{k}} \pm 0.12$ & $4.81^{\mathrm{gh}} \pm 0.08$ & $14.31^{\mathrm{m}} \pm 0.04$ \\
\hline 9 & $91.18^{\mathrm{fgh}} \pm 0.05$ & $20.13^{\mathrm{g}} \pm 0.07$ & $2.84^{\mathrm{bcd}} \pm 0.05$ & $5.88^{\mathrm{i}} \pm 0.03$ & $19.69^{j} \pm 0.11$ & $4.98^{\mathrm{f}} \pm 0.03$ & $14.71^{1} \pm 0.08$ \\
\hline 10 & $91.52^{\mathrm{e}} \pm 0.07$ & $20.53^{\mathrm{fe}} \pm 0.09$ & $2.81^{\mathrm{bcd}} \pm 0.07$ & $5.96^{\mathrm{h}} \pm 0.05$ & $20.62^{\mathrm{h}} \pm 0.18$ & $5.38^{\mathrm{c}} \pm 0.08$ & $15.24^{\mathrm{k}} \pm 0.1$ \\
\hline 11 & $91.34^{\mathrm{efg}} \pm 0.04$ & $21.17^{\mathrm{d}} \pm 0.01$ & $2.66^{\mathrm{cde}} \pm 0.1$ & $6.12^{\mathrm{efg}} \pm 0.02$ & $21.57^{\mathrm{e}} \pm 0.03$ & $5.09^{\mathrm{de}} \pm 0.03$ & $16.48^{\mathrm{h}} \pm 0.042$ \\
\hline 12 & $91.38^{\mathrm{ef}} \pm 0.02$ & $21.84^{\mathrm{b}} \pm 0.04$ & $2.39^{\mathrm{efg}} \pm 0.09$ & $6.23^{\mathrm{d}} \pm 0.03$ & $22.54^{\mathrm{b}} \pm 0.18$ & $5.42^{\mathrm{c}} \pm 0.07$ & $17.12^{\mathrm{b}} \pm 0.11$ \\
\hline 13 & $91.21^{\mathrm{fgh}} \pm 0.05$ & $22.38^{\mathrm{a}} \pm 0.11$ & $2.11^{\mathrm{gh}} \pm 0.04$ & $6.31^{\mathrm{c}} \pm 0.04$ & $22.9^{\mathrm{a}} \pm 0.05$ & $5.53^{\mathrm{b}} \pm 0.03$ & $17.37^{\mathrm{a}} \pm 0.02$ \\
\hline 14 & $91.84^{\mathrm{cd}} \pm 0.08$ & $21.39^{\mathrm{cd}} \pm 0.04$ & $2.9^{\mathrm{bc}} \pm 0.04$ & $6.14^{\mathrm{ef}} \pm 0.01$ & $21.24^{f} \pm 0.06$ & $4.64^{\mathrm{j}} \pm 0.01$ & $16.6^{\mathrm{gh}} \pm 0.05$ \\
\hline 15 & $91.94^{\mathrm{cd}} \pm 0.05$ & $21.41^{\mathrm{c}} \pm 0.01$ & $2.86^{\mathrm{bcd}} \pm 0.02$ & $6.15^{\mathrm{e}} \pm 0.03$ & $21.58^{\mathrm{e}} \pm 0.11$ & $4.87^{\mathrm{g}} \pm 0.07$ & $16.71 \mathrm{f}^{\mathrm{g}} \pm 0.04$ \\
\hline 16 & $92.46^{\mathrm{a}} \pm 0.06$ & $21.25^{\mathrm{cd}} \pm 0.05$ & $2.66^{\text {cde }} \pm 0.13$ & $6.07^{\mathrm{g}} \pm 0.05$ & $21.56^{\mathrm{e}} \pm 0.12$ & $4.74^{\text {ih }} \pm 0.1$ & $16.82^{\text {def }} \pm 0.02$ \\
\hline 17 & $92.04^{b} \pm 0.04$ & $21.25^{\mathrm{cd}} \pm 0.02$ & $2.57^{\mathrm{def}} \pm 0.02$ & $6.11^{\mathrm{efg}} \pm 0.04$ & $22.13^{c} \pm 0.08$ & $5.17^{\mathrm{d}} \pm 0.02$ & $16.96^{\mathrm{c}} \pm 0.06$ \\
\hline 18 & $91.51^{\mathrm{e}} \pm 0.03$ & $21.2^{\mathrm{cd}} \pm 0.03$ & $2.4^{\mathrm{efg}} \pm 0.06$ & $6.12^{\mathrm{efg}_{ \pm}} 0.02$ & $21.92^{\mathrm{d}} \pm 0.11$ & $5.04^{\mathrm{fe}} \pm 0.04$ & $16.88^{\text {cd }} \pm 0.07$ \\
\hline 19 & $91.27^{\mathrm{fgh}} \pm 0.07$ & $21.23^{\mathrm{cd}} \pm 0.02$ & $2.21^{\mathrm{gh}} \pm 0.02$ & $6.08^{\mathrm{fg}} \pm 0.02$ & $22.62^{\mathrm{b}} \pm 0.08$ & $5.78^{\mathrm{a}} \pm 0.06$ & $16.84^{\mathrm{de}} \pm 0.02$ \\
\hline 20 & $91.49^{\mathrm{e}} \pm 0.04$ & $21.18^{\mathrm{cd}} \pm 0.02$ & $2.16^{\mathrm{gh}} \pm 0.11$ & $6.1^{\mathrm{efg}} \pm 0.03$ & $22.12^{\mathrm{c}} \pm 0.18$ & $5.38^{\mathrm{c}} \pm 0.08$ & $16.74^{\mathrm{ef}} \pm 0.1$ \\
\hline
\end{tabular}

a-o - means within in a column with different letters differ at $\mathrm{P} \leq 0.05$; TDF - total dietary fibre; SDF - soluble dietary fibre; IDF - insoluble dietary fibre; d.w. - dry weight

Increasing shares of MBP (from 5 to $30 \%$ ) led to a distinct increase in the content of $\mathrm{Ca}, \mathrm{Fe}, \mathrm{Zn}, \mathrm{Cu}, \mathrm{Cr}, \mathrm{Ni}$ and a slight increase in the level of $\mathrm{Na}$ and $\mathrm{Mg}$ (Tab. 5). At the same time, the content of $\mathrm{K}$ did not change significantly. Moreover, a notable drop in the content of Mn was noted, probably as a result of increase in the content of the meat component, at the expense of reduced levels of faba bean and wheat grain meals.

The extruded samples were characterised by a big diversity of form and structure. That diversity resulted both from the varied raw material composition and from the variable process temperature. The sample containing $20 \%$ of meat-bone pulp and $80 \%$ of wheat grain meal, presented in Figure 1, was characterised by a low specific density and relatively high degree of expansion. The product had an irregular, porous macrostructure (Fig. 1A). The size of air pores was highly various and ranged from 
several to few hundreds micrometres. There is an observable absence of a distinct cellular structure of the extrudates, characteristic for expanded products. The product appears to be insufficiently processed. However, analysis of the microstructure (Figs $1 \mathrm{~B}-\mathrm{C})$ revealed that during the process of extrusion the material processed was completely liquefied. The microstructure has the form of a liquefied and set mass, with small pores with the size of less than twenty micrometres. At magnification of x1000 (Fig. 1C) one can see melted starch granules, encased in a protein matrix.

Table 5. Composition of macro- and microelements in the extrudates ( $\mathrm{m} \mathrm{kg}^{-1}$ d.w.)

\begin{tabular}{|c|c|c|c|c|c|c|c|c|c|c|}
\hline \multirow{2}{*}{ Sample } & \multicolumn{4}{|c|}{ Macroelements } & \multicolumn{6}{|c|}{ Microelements } \\
\hline & $\mathrm{K}$ & $\mathrm{Ca}$ & $\mathrm{Na}$ & $\mathrm{Mg}$ & $\mathrm{Fe}$ & $\mathrm{Cu}$ & $\mathrm{Mn}$ & $\mathrm{Ni}$ & $\mathrm{Cr}$ & $\mathrm{Zn}$ \\
\hline 1 & $1735^{\text {fedc }}$ & $1140^{\mathrm{m}}$ & $421^{j}$ & $1554^{\mathrm{k}}$ & $47.953^{f}$ & $6.69^{j}$ & $40.686^{\mathrm{ed}}$ & $0.639^{\mathrm{h}}$ & $0.528^{b}$ & $46.917^{\mathrm{ji}}$ \\
\hline 2 & $1727^{\text {fedc }}$ & $1290^{1}$ & $421^{j}$ & $1576^{\mathrm{j}}$ & $50.08^{\mathrm{e}}$ & $6.72^{j}$ & $38.851^{\mathrm{f}}$ & $0.761^{\mathrm{g}}$ & $0.26^{\mathrm{f}}$ & $48.03^{\text {ihg }}$ \\
\hline 3 & $1715^{\text {fed }}$ & $1410^{\mathrm{k}}$ & $432^{\mathrm{ji}}$ & $1680^{\mathrm{hg}}$ & $52.775^{c}$ & $6.67^{\mathrm{j}}$ & $35.08^{\mathrm{g}}$ & $0.88^{\mathrm{f}}$ & $0.44^{\mathrm{dc}}$ & $49.26^{\mathrm{gfe}}$ \\
\hline 4 & $1715^{\text {fed }}$ & $1600^{j}$ & $452^{\text {hgf }}$ & $1702^{\text {edc }}$ & $53.848^{\mathrm{c}}$ & $7.0^{\text {ihg }}$ & $32.79^{\mathrm{h}}$ & $0.96^{\mathrm{fe}}$ & $0.41^{\mathrm{ed}}$ & $50.443^{\text {edcb }}$ \\
\hline 5 & $1700^{\mathrm{fe}}$ & $1780^{\mathrm{i}}$ & $482^{b}$ & $1705^{\mathrm{edc}}$ & $55.843^{\text {ba }}$ & $7.18^{\mathrm{gfe}}$ & $30.189^{\mathrm{i}}$ & $1.001^{\mathrm{ed}}$ & $0.421^{\mathrm{edc}}$ & c $51.734^{\mathrm{ba}}$ \\
\hline 6 & $1670^{\mathrm{f}}$ & $2450^{\mathrm{h}}$ & $522^{\mathrm{a}}$ & $1777^{\mathrm{a}}$ & $56.594^{\mathrm{a}}$ & $7.55^{\mathrm{b}}$ & $29.603^{\mathrm{i}}$ & $1.11^{\mathrm{cb}}$ & $0.645^{\mathrm{a}}$ & $52.53^{\mathrm{a}}$ \\
\hline 7 & $1221^{i}$ & $2440^{\mathrm{h}}$ & $441^{\mathrm{hg}}$ & $1668^{h}$ & $50.43^{e}$ & $6.047^{f}$ & $38.872^{f}$ & $0.603^{h}$ & $0.38^{\mathrm{e}}$ & $45.905^{j}$ \\
\hline 8 & $1428^{\mathrm{h}}$ & $2660^{\mathrm{g}}$ & $450^{\mathrm{hg}}$ & $1653^{\mathrm{i}}$ & $51.03^{\text {ed }}$ & $6.918^{\text {ih }}$ & $39.406^{\mathrm{f}}$ & $0.94^{\mathrm{fe}}$ & $0.465^{\mathrm{dc}}$ & $47.42^{\mathrm{hi}}$ \\
\hline 9 & $1553^{\mathrm{g}}$ & $2820^{\mathrm{f}}$ & $458^{\mathrm{gfe}}$ & $1699^{\text {ed }}$ & $52.96^{\mathrm{c}}$ & $7.367^{\text {edcb }}$ & $40.59^{\mathrm{ed}}$ & $1.007^{\mathrm{edc}}$ & $0.47^{\mathrm{c}}$ & $48.5^{\text {hgf }}$ \\
\hline 10 & $1753^{\text {fedc }}$ & $3160^{\mathrm{e}}$ & $461^{\text {gfed }}$ & $1683^{g f}$ & $53.204^{\mathrm{c}}$ & $7.471^{\mathrm{dcb}}$ & $40.623^{\mathrm{ed}}$ & $0.95^{\mathrm{fe}}$ & $0.42^{\text {edc }}$ & $49.917^{\mathrm{fed}}$ \\
\hline 11 & $1795^{\text {edc }}$ & $3190^{\mathrm{e}}$ & $469^{\text {fedcb }}$ & $1694^{\mathrm{gfed}}$ & $53.652^{\mathrm{c}}$ & $7.51^{\mathrm{cb}}$ & $42.982^{b}$ & $1.08^{\mathrm{dcb}}$ & $0.312^{\mathrm{f}}$ & $50.937^{\mathrm{dcb}}$ \\
\hline 12 & $1966^{\mathrm{b}}$ & $3290^{\mathrm{cb}}$ & $477^{\mathrm{dcb}}$ & $1728^{\mathrm{b}}$ & $54.295^{\mathrm{cb}}$ & $8.144^{\mathrm{a}}$ & $44.19^{\mathrm{a}}$ & $1.18^{\mathrm{ba}}$ & $0.42^{\text {edc }}$ & $51.747^{\mathrm{ba}}$ \\
\hline 13 & $2078^{a}$ & $3710^{\mathrm{a}}$ & $479^{\mathrm{cb}}$ & $1774^{\mathrm{a}}$ & $55.803^{\text {ba }}$ & $8.247^{\mathrm{a}}$ & $44.24^{\mathrm{a}}$ & $1.25^{\mathrm{a}}$ & $0.274^{\mathrm{f}}$ & $51.62^{\mathrm{cba}}$ \\
\hline 14 & $1798^{\text {edc }}$ & $3220^{\text {ed }}$ & $459^{\mathrm{gfe}}$ & $1696^{\mathrm{fed}}$ & $53.086^{\mathrm{c}}$ & $7.25^{\mathrm{fe}}$ & $40.948^{d}$ & $0.941^{\mathrm{fe}}$ & $0.3^{\mathrm{f}}$ & $49.58^{\text {fed }}$ \\
\hline 15 & $1829^{c}$ & $3280^{\mathrm{dc}}$ & $463^{\text {gfedc }}$ & $1692^{\mathrm{gfe}}$ & $52.58^{\mathrm{dc}}$ & $7.31^{\mathrm{ed}}$ & $42.988^{b}$ & $0.972^{\text {fe }}$ & $0.28^{\mathrm{f}}$ & $50.003^{\text {fedc }}$ \\
\hline 16 & $1826^{\mathrm{c}}$ & $3280^{\mathrm{dc}}$ & $471^{\text {edcb }}$ & $1707^{\text {edc }}$ & $53.534^{\mathrm{c}}$ & $7.027^{\mathrm{hg}}$ & $43.07^{\mathrm{b}}$ & $0.95^{\mathrm{fe}}$ & $0.29^{f}$ & $50.23^{\mathrm{edcb}}$ \\
\hline 17 & $1819^{\mathrm{dc}}$ & $3300^{\mathrm{cb}}$ & $469^{\text {fedcb }}$ & $1704^{\text {edc }}$ & $53.527^{\mathrm{c}}$ & $6.82^{\mathrm{ji}}$ & $40.109^{\mathrm{e}}$ & $0.99^{\text {ed }}$ & $0.3^{\mathrm{f}}$ & $50.763^{\text {edcb }}$ \\
\hline 18 & $1817^{\mathrm{dc}}$ & $3320^{\mathrm{cb}}$ & $473^{\text {edcb }}$ & $1709^{\mathrm{dc}}$ & $53.52^{\mathrm{c}}$ & $7.087^{\text {hgf }}$ & $42.00^{\mathrm{c}}$ & $0.97^{\mathrm{fe}}$ & $0.32^{\mathrm{f}}$ & $50.323^{\text {edcb }}$ \\
\hline 19 & $1820^{\mathrm{dc}}$ & $3300^{\mathrm{cb}}$ & $472^{\text {edcb }}$ & $1715^{\mathrm{cb}}$ & $53.52^{c}$ & $7.29^{\mathrm{fed}}$ & $43.52^{\mathrm{ba}}$ & $1.08^{\mathrm{dcb}}$ & $0.27^{\mathrm{f}}$ & $50.07^{\mathrm{fedc}}$ \\
\hline 20 & $1817^{\mathrm{dc}}$ & $3360^{b}$ & $465^{\text {fedcb }}$ & $1704^{\text {edc }}$ & $53.521^{\mathrm{c}}$ & $7.25^{\mathrm{fe}}$ & $43.83^{\mathrm{a}}$ & $1.11^{\mathrm{cb}}$ & $0.28^{\mathrm{f}}$ & $50.69^{\text {edcb }}$ \\
\hline
\end{tabular}

$\mathrm{a}-\mathrm{m}-$ means within in a column with different letters differ at $\mathrm{P} \leq 0.05$

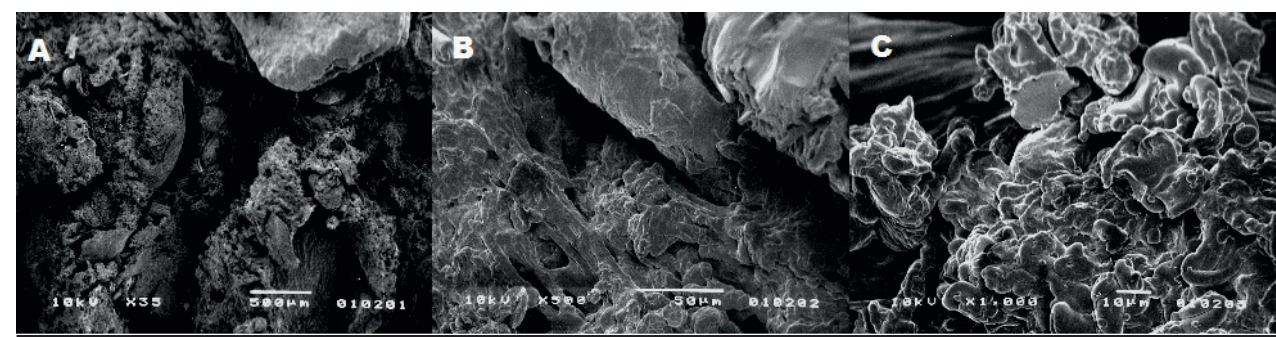

Fig. 1. Scanning electron macro- and micrographs of extruded products. raw composition: $20 \%$ meatbone pulp and $80 \%$ wheat; profile of barrel temperature: $120 / 140 / 180 / 180 / 130^{\circ} \mathrm{C}$. magnification: a) x35; b) $\times 500$; c) $\times 1000$ 


\section{Effect of the concentration of faba bean meal (FBM)}

Increase in the content of FBM at constant extrusion conditions did not significantly affect the degree of radial expansion and WSI, but it did cause an increase in the specific density and impact strength of the products (Tab. 3). The highest impact strength $\left(0.096 \mathrm{~J} \mathrm{~cm}^{-2}\right)$ was characteristic of extrduates composed of $20 \% \mathrm{MBP}$, $30 \% \mathrm{FBM}$ and 50\% WGM (sample 13) (Tab. 3).

The introduction of FBM to the wheat-meat blends led to an increase of protein content in the extrudates. Products without an addition of FBM (sample 7) contained $19.12 \%$ d.w. of protein, while those with $30 \%$ share of faba bean $-22.38 \%$ d.w. (Tab. 4 ). The introduction of a greater share of FBM increased also the content of TDF, IDF and SDF. At the same time, a decrease in the fat content was observed (Tab. 4).

As a result of the introduction of FBM, a significant increase (Duncan test, $\mathrm{P} \leq 0.05$ ) was noted in the contents of $\mathrm{K}, \mathrm{Ca}, \mathrm{Na}, \mathrm{Mg}, \mathrm{Fe}, \mathrm{Mn}, \mathrm{Zn}, \mathrm{Cu}$ and Ni. Only in the case of $\mathrm{Cr}$ content no clear tendency was observed (Tab. 5).

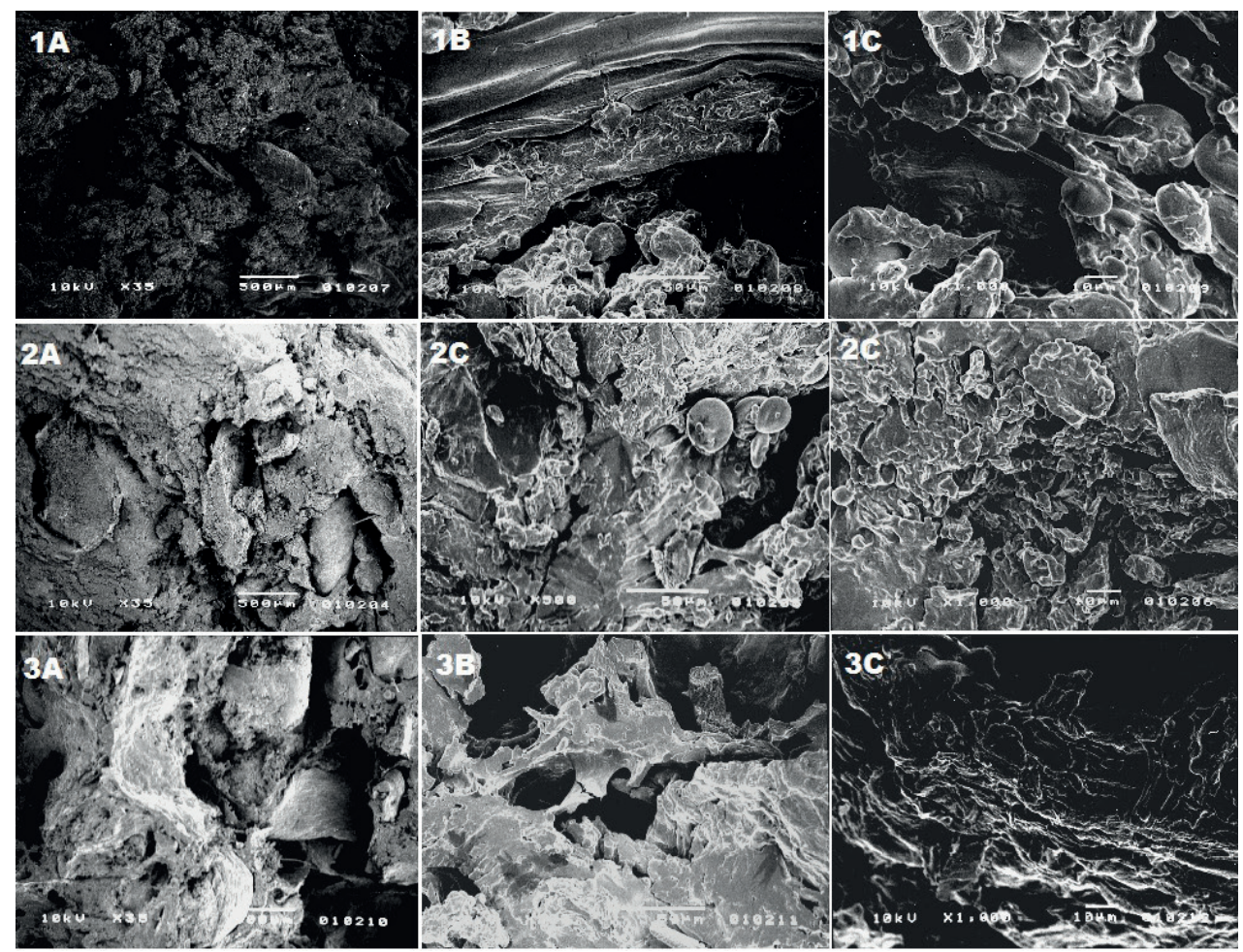

Fig. 2. Scanning electron macro- and micrographs of extruded products. raw composition: $20 \%$ meatbone pulp, $20 \%$ faba bean and $60 \%$ wheat; profile of barrel temperature: 1) $90 / 110 / 130 / 130 / 130^{\circ} \mathrm{C}$; 2) $120 / 140 / 180 / 180 / 130^{\circ} \mathrm{C}$; 3) $150 / 180 / 250 / 250 / 130^{\circ} \mathrm{C}$. magnification: a) $\mathrm{x} 35$; b) $\mathrm{x} 500$; c) $\mathrm{x} 1000$ 
The addition of faba bean at the dose of $20 \%$, with simultaneous reduction of the share of wheat grain meal to $60 \%$ (sample 11), caused an increase of specific density of the extrudate. The microstructure of the products become densely-packed, compact, with hard texture (Figs 2-2A). The cell walls were thick, with characteristic fraying. There were air pores with sizes from about one micrometre to over ten micrometres (Figs 2-2B and 2-2C). The structure of the cell walls had the form of small melted fragments of the material, encased in protein mass.

\section{Effect of the process temperature}

Increase of the extrusion temperature of blends with a constant material composition (20\% MBP, 20\% FBM, 60\% WGM) caused an increase in the degree of radial expansion and impact strength of the products (Tab. 3). At the same time, a decrease of specific density was observed. No significant changes were noted in the values of WSI.

The study showed no significant changes in protein and ash content as a function of the process temperature. Whereas, with increase in the process temperature from $130^{\circ} \mathrm{C}$ to $250^{\circ} \mathrm{C}$, determinability of fat decreased from 2.9 to $2.16 \%$ d.w. The use of high extrusion temperatures caused an increase in the contents of TDF as well as SDF (Tab. 4).

Process temperature did not have any significant effect on the content of macroelements $(\mathrm{K}, \mathrm{Ca}, \mathrm{Na}$ and $\mathrm{Mg}$ ) and microelements $(\mathrm{Fe}, \mathrm{Cu}, \mathrm{Cr}$ and $\mathrm{Zn})$ in the extrudates (Tab. 5).

The study demonstrated a very strong effect of extrusion temperature on the internal structure of the product. Application of low process temperatures $\left(130^{\circ} \mathrm{C}\right)$ resulted in the appearance of cohesive and compacted, gritty-like structure (Figs 2-1A). This product was characterised by low expansion ratio and low impact strength. Photographs of microstructure (Figs 2-1B and 1C) reveal non-liquefied starch granules, encased in and delicately bonded with thin protein bridges. Most probably, under conditions of low extrusion temperature and the protective action of fat, starch was not completely gelatinised. Increase of extrusion temperature caused a clearly visible change in the microstructure of the products (Figs 2-2A and 2-3A). The gritty-like macrostructure observed earlier, disappeared. At a magnification x500 (Figs 2-3B) one can clearly see homogeneous cell walls and air spaces with sizes of as much as tens of micrometres. The confirmation of complete liquefaction of the material is the image of microstructure visible in Figures 2-3C. Cell walls have the form of multi-layered structures, built of flat and well-liquefied fragments of material. 


\section{DISCUSSION}

The application of twin-screw counter-rotating extrusion permitted the processing of plant-meat blends with the content of the meat component of up to $30 \%$. Any higher content of the meat-bone pulp caused an excessive moisture of the material, which led to the material sticking to the feeder screws and the extruder screws. The disturbances observed in material dosage caused non-uniform flow of the mass in the extruder barrel. That resulted in the material caking on the barrel walls and on the screws, and blocking the extruder.

Products with MBP were characterised by a relatively low degree of expansion and a thick and compact structure. Colona et al. (1989) report that the diameter of products of pet food type should be about $200-300 \%$ relative to the die diameter. The resulting products were characterised by slightly lower expansion. The content of MBP was positively correlated with radial expansion and negatively correlated with specific density (Tab. 6). The tendency noted could have been a result of increase in the content of fat in the extruded blend. According to Colona et al. (1989), fat content increase to 5\% resulted in an increase in the degree of radial expansion. Many researchers have found an opposite effect in the case of increase of protein content. Allen et al. (2007) observed a decrease in radial expansion and an increase in specific density of extrudates, with an increase in the content of protein in maize extrudates. Seker (2005) claims that the formation of a strong protein matrix can inhibit the liberation of water vapour from the product exiting the die of the extruder, and contribute to the formation of a compact and dense structure of extrudates. The presented study, however, did not confirm aforementioned results. The increase in the share of high-protein materials such as MBP and FBM had no impact on the decrease in the degree of expansion ratio.

Table 6. Regression models for the physical properties

\begin{tabular}{|c|c|c|c|c|c|c|c|c|c|c|c|c|}
\hline & \multicolumn{3}{|c|}{ Expansion ratio } & \multicolumn{3}{|c|}{ Specific density } & \multicolumn{3}{|c|}{ Impact strength } & \multicolumn{3}{|c|}{ WSI } \\
\hline & $\mathrm{B}_{\mathrm{W}}$ & $\mathrm{SE}$ & P-value & $\mathrm{B}_{\mathrm{W}}$ & SE & P-value & $\mathrm{B}_{\mathrm{w}}$ & SE & P-value & $\mathrm{B}_{\mathrm{W}}$ & SE & P-value \\
\hline Intercept & 1.043 & 0.177 & $<0.0001$ & 1069.61 & 44.33 & $<0.0001$ & 0.004 & 0.016 & 0.8000 & 8.910 & 0.270 & $<0.0001$ \\
\hline Meat-bone pulp & 0.009 & 0.004 & 0.06 & -3.91 & 1.03 & 0.0016 & 0.001 & 0.000 & 0.0081 & 0.120 & 0.010 & $<0.0001$ \\
\hline Faba bean meal & - & - & - & 2.39 & 0.78 & 0.0076 & 0.001 & 0.000 & 0.0005 & - & - & - \\
\hline $\begin{array}{l}\text { Extrusion } \\
\text { temperature }\end{array}$ & 0.004 & 0.001 & 0.0001 & -0.59 & 0.20 & 0.0100 & 0.001 & 0.000 & 0.0660 & - & - & - \\
\hline $\mathrm{R}^{2}$ & 0.62 & & & 0.69 & & & 0.66 & & & 0.81 & & \\
\hline
\end{tabular}

WSI - Water solubility index; $\mathrm{B}_{\mathrm{w}}$ - Regression coefficients ; SE - Standard error; P-value - only significant variables shown. Backward elimination of insignificant variables

An increase of radial expansion was noted as a result of increase in the process temperature (Tab. 6). At the same time, there was a visible decrease in the specific density of extrudates. The tendency observed resulted from better liquefaction of 
the mass and lowering of its viscosity under conditions of higher extrusion temperatures. Well liquefied mass passed more easily through the die apertures, causing more intensive expansion of the products, and hence a drop in the specific density of extrudates. Similar trends were noted by Rzedzicki at al. (2004) and by Balandran-Quintana et al. (1998).

In the case of extrudates for animal feed, the texture and hardness of the products are of high importance. Especially in the diet of carnivores (e.g. dogs, cats), a compact and hard structure is desirable. Increase the contents of both MBP and FBM in the extrudates caused an increase in the impact strength of the products (Tab. 6). According to Faubion and Hoseney (1982), the tendency observed may be a result of increase in protein content. The impact strength of the products was also significantly affected by the process temperature (Tab. 6). The highest impact strength $\left(0.087 \mathrm{~J} \mathrm{~cm}^{-2}\right.$, sample 17$)$ was characteristic of products extruded at temperature of $190^{\circ} \mathrm{C}$. Temperature increase above that value caused increased degradation of the product and loosening of its structure, manifested in lowered hardness of products $\left(0.073 \mathrm{~J} \mathrm{~cm}^{-2}\right.$, sample 20$)$. A similar relationship was noted by Colona et al. (1989).

Increase in the content of the meat component in the extruded blend led to a decrease of WSI of extrudates (Tab. 6). Fat contained in the meat component could have caused a lubricating effect and thus decrease the shear rate gradient. Reduced friction slowed down the depolymerisation of starch, the consequence of which was a decrease of WSI. It should be mentioned that increase in fat content intensifies the formation of insoluble starch-lipid complexes, which in the opinion of Colona et al. (1989) can also be a cause of decrease in WSI values of products. This is supported by the research of Van Hoan et al. (2010) who, extruding ricesoybean blends enriched with an addition of soybean oil, noted a decrease of WSI with increase of fat content in the material extruded. In addition, increasing share of meat component was related with a lower level of high-starch plant components: wheat and faba bean. According to Colona et al. (1989) and Ding et al. (2005), it is mainly the content of starch and the degree of its depolymerisation that determine the value of WSI of extrudates. Decrease in the content of starch in the extruded material could also have been a cause of the decrease of WSI. Pet food should be characterised by low values of WSI. Such products are digested slowly and will give a feeling of satiety for a long of time after ingestion (Brennan et al. 2012).

Literature data indicate that an increase of extrusion temperature leads to an increase in the value of WSI (Ding et al. 2006, Singh et al. 2007). This study showed that the extrusion temperature did not cause any significant changes in the values of WSI (Tab. 6). The important role in this case was that of a high moisture content of the extruded material, inhibiting the depolymerisation of starch. Increase 
of extrusion temperature was also conducive to increased complexation of lipids. The formation of insoluble starch-lipid complexes could also have had an effect on relatively low WSI values of products obtained at high temperature of extrusion.

Increase in the levels of the meat component and the leguminous component caused an increase in the contents of protein and ash in the extrudates (Tab. 7). Whereas, an increase in fat content in the products was noted only as a result of addition of the fat-rich meat-bone pulp. The concentrate of the meat component in the extrudates was negatively correlated with the content of dietary fibre (Tab. 7). Extrusion-cooking causes partial degradation of molecular mass of fibre components and lowering of their determinability on the one hand, while on the other hand extrusion may be conductive to the formation of new fibre components e.g. resistant starch or products of the Maillard reaction (Singh et al. 2007, Sobota and Rzedzicki 2009). Therefore, the content of dietary fibre fractions determined in the extrudates is the result of the above processes. Increase of extrusion temperature from 130 to $250^{\circ} \mathrm{C}$ caused a significant increase in the contents of TDF and SDF fractions. No significant changes in the content of IDF were observed.

Table 7. Regression models for crude protein, crude fat, ash and TDF content

\begin{tabular}{|c|c|c|c|c|c|c|c|c|c|c|c|c|}
\hline & \multicolumn{3}{|c|}{ Crude protein } & \multicolumn{3}{|c|}{ Crude fat } & \multicolumn{3}{|c|}{ Ash } & \multicolumn{3}{|c|}{ TDF } \\
\hline & $B_{w}$ & $\mathrm{SE}$ & P-value & $B_{W}$ & SE & P-value & $\mathrm{B}_{\mathrm{W}}$ & $\mathrm{SE}$ & P-value & $\mathrm{B}_{\mathrm{w}}$ & SE & P-value \\
\hline Intercept & 160.49 & 1.31 & $<0.0001$ & 27.16 & 3.12 & $<0.0001$ & 23.71 & 0.77 & $<0.0001$ & 122.19 & 8.65 & $<0.0001$ \\
\hline Meat-bone pulp & 1.48 & 0.05 & $<0.0001$ & 0.82 & 0.07 & $<0.0001$ & 1.63 & 0.03 & $<0.0001$ & -2.04 & 0.20 & $<0.0001$ \\
\hline Faba bean meal & 1.11 & 0.04 & $<0.0001$ & -0.26 & 0.05 & $<0.0003$ & 0.23 & 0.02 & $<0.0001$ & 1.65 & 0.15 & $<0.0001$ \\
\hline $\begin{array}{l}\text { Extrusion } \\
\text { temperature }\end{array}$ & - & - & - & .07 & 0.01 & 0.0002 & - & - & & 0.10 & 0.04 & $<0.0170$ \\
\hline$\overline{R^{2}}$ & 0.99 & & & 0.92 & & & 0.99 & & & 0.93 & & \\
\hline
\end{tabular}

TDF - total dietary fibre, WSI - Water solubility index; $B_{w}-$ Regression coefficients ; SE- Standard error; P-value - only significant variables shown. Backward elimination of insignificant variables

Increase of the temperature of extrusion may lead to an increase in the content of certain microelements ( $\mathrm{Fe}, \mathrm{Ni})$. This is related with the wear of the working parts of the extruder and with migration of elements to the product. However, in the presented study, extrusion temperature had no significant effect on the levels of most macro- and microelements (Duncan test, $\mathrm{P} \leq 0.05$ ). The decisive role in this case could have been that of high moisture of the material and high content of fat which were factors reducing the intensity of friction of the material against the working elements of the extruder. Therefore, the results obtained do not support the data obtained by Camire et al. (1993). Those authors concluded that the process temperature could have a significant effect on the rate of wear of the working elements of the extruder and on the migration of alloy elements of steel (mainly $\mathrm{Fe}$ ) to the products. Also Alonso et al. (2001) noted a higher content of Fe in extruded pea and beans compared to the raw material. 


\section{CONCLUSION}

The "dry" extrusion of blends with a content of MBP proceeded correctly within a broad range of parameters. The products obtained were characterised by diverse physical properties and chemical composition. The recommended parameters of the process of "dry" extrusion of blends of MBP with plant materials (FBM and WGM) are as follows: meat bone-pulp content of up to $30 \%$, raw material moisture: $28 \%$, profile of temperature distribution in the extruder cylinder: $120 / 140 / 180 / 180 / 130^{\circ} \mathrm{C}$; die diameter 3 × $6 \mathrm{~mm}$, screw speed $75 \mathrm{rpm}$. The application of wheat and faba bean as the plant materials permitted the obtainment of products with cohesive structure and high impact strength, and resistant to crushing. After supplementation of the material blend with taste and flavour components, they can be excellent dry food for dogs and cats.

\section{REFERENCES}

AACC, 2000. Approved Methods of the American Association of Cereal Chemists. AACC Press, St. Paul. AOAC, 1990. Official Methods of Analysis of the Association of Analytical Chemists, AOAC Press, Arlington-Virginia.

Allen K.E., Carpenter C.E., Walsh M.K., 2007. Influence of protein level and starch type on an extrusion-expanded whey product. Int. J. Food Sci. Technol., 42, 953-960, doi:10.1111/ j.1365-2621.2006.01316.x

Alonso R., Rubio L.A., Muzquiz M., Marzo F., 2001. The effect of extrusion cooking on mineral bioavailability in pea and kidney bean seed meals. Anim. Feed Sci. Technol., 94(1-2), 1-13, doi:10.1016/S0377-8401(01)00302-9

Ayadi F.Y., Rosentrater K.A., Muthukumarappan K., Brown M.L., 2012. Twin-screw extrusion processing of distillers dried grains with soluble (DDGS)-based yellow perch (Perca flavescens) feeds. Food Bioprocess. Technol., 5, 1963-1978, doi:10.1007/s11947-011-0535-5

Balandran-Quintana R.R., Barbosa-Canovas G.V., Zazueta-Morales J.J., Anzaldua-Morales A., Quintero-Ramos A., 1998. Functional and nutritional properties of extruded whole pinto bean meal (Phaseolus Vulgaris L.). J. Food Sci., 1, 113-116, doi:10.1111/j.1365-2621.1998.tb15688.x

Brennan M.A., Derbyshire E., Tiwari B.K., Brennan C.S., 2012. Enrichment of Extruded Snack Products with Coproducts from Chestnut Mushroom (Agrocybe aegerita) Production: Interactions between Dietary Fiber, Physicochemical Characteristics, and Glycemic Load. J. Agric. Food Chem., 60, 4396-4401, doi:10.1021/jf3008635

Camire M., Zhao J., Violette D.A., 1993. In vitro binding of bile acids by extruded potato peels. J. Agric. Food Chem., 41, 2391-2394, doi:10.1021/jf00036a033

Castells M., Marin S., Sanchis V., Ramos A.J., 2005. Fate of mycotoxins in cereals during extrusion cooking: a review. Food Addit. Contam., 22, 150-157, doi:10.1080/02652030500037969

Colona P., Tayeb J., Mercier C., 1989. Extrusion cooking of starch and starchy products. In: Extrusion Cooking (Eds C. Mercier, P. Linko, J.M. Harper), AACC Inc.; Saint Paul, 247-320.

Ding Q-B., Ainsworth P., Tucker G., Marson H., 2005. The effect of extrusion conditions on the physicochemical properties and sensory characteristics of rice-based expanded snacks. J. Food Eng., 66(3), 283-289, doi:10.1016/j.jfoodeng.2004.03.019 
Ding Q-B., Ainsworth P., Plunkett A., Tucker G., Marson H., 2006. The effect of extrusion conditions on the functional and physical properties of wheat-based expanded snacks. J. Food Eng., 73(2), 142-148, doi:10.1016/j.jfoodeng.2005.01.013

Faubion J.M., Hoseney R.C., 1982. High-temperature short-time extrusion cooking of wheat starch and flour. II. Effect of protein and lipid on extrudate properties. Cereal Chem., 59, 533-537.

Guz L., Puk K., Walczak N., Oniszczuk T., Oniszczuk A., 2014. Effect of dietary supplementation with Echinacea purpurea on vaccine efficacy against infection with Flavobacterium columnare in zebrafish (Danio rerio). Pol. J. Vet. Sci., 17(4), 583-586, doi:10.2478/pjvs-2014-0087

Guz L., Sopińska A., Oniszczuk T., 2011. Effect of Echinacea purpurea on growth and survival of guppy (Poecilia reticulata) challenged with Aeromonas bestiarum. Aquac. Nutr., 17(6), 695-700, doi:10.1111/j.1365-2095.2011.00873.x

Likimani T.A., Sofos J.N., 1990. Bacterial spore injury during extrusion cooking of corn/soybean mixtures. Int. J. Food Microbiol., 11(3-4), 243-249, doi:10.1016/0168-1605(90)90017-Y

Okelo P.O., Wagner D.D., Carr L.E., Wheaton F.W., Douglass L.W., Joseph S.W., 2006. Optimization of extrusion conditions for elimination of mesophilic bacteria during thermal processing of animal feed mash. Anim. Feed Sci. Tech., 129, 116-137, doi:10.1016/j.anifeedsci.2005.12.011

Oniszczuk T., Oniszczuk A., Gondek E., Guz L., Puk K., Kocira A., Kusz A., Kasprzak K., Wójtowicz A., 2017. Active polyphenolic compounds, nutrient contents and antioxidant capacity of extruded fish feed containing purple coneflower (Echinacea purpurea (L.) Moench.). Saudi J. Biol. Sci., doi:10.1016/j.sjbs.2016.11.013

Rzedzicki Z., Szpryngiel B., Sobota A., 2000. Estimation of some chosen physical properties of extrudates obtained from corn semolina and oat bran mixtures. Int. Agrophys., 14, 233-239.

Rzedzicki Z., Sobota A., Zarzycki P., 2004. Study on the process of single-screw extrusion-cooking of mixtures with a content of pea hulls. Int. Agrophys., 18(1), 73-82.

Samuelsen T.A., Mjøs S.A., Oterhals Å., 2013. Impact of variability in fishmeal physicochemical properties on the extrusion process, starch gelatinization and pellet durability and hardness. Anim. Feed Sci. Tech., 179, 77-84, doi:10.1016/j.anifeedsci.2012.10.009

Seker M., 2005. Selected properties of native or modified maize starch/soy protein mixtures extruded at varying screw speed. J. Sci. Food Agr., 85, 1161-1165, doi:10.1002/jsfa.2086

Singh B., Sekhon K.S., Singh N., 2007. Effects of moisture, temperature and level of pea grits on extrusion behaviour and product characteristics of rice. Food Chem., 100, 198-202, doi:10.1016/j. foodchem.2005.09.042

Sobota A., Rzedzicki Z., 2009. Effect of the extrusion process of corn semolina and pea hulls blends on chemical composition and selected physical properties of the extrudates. Int. Agrophys., 23(1), 67-79.

Van De Velde C., Bounie D., Cuq J.L., Cheftel J.C., 1984. Destruction of microorganism and toxins by extrusion-cooking. In: Thermal Processing and Quality of Foods (Eds P. Zeuthen, J.C. Cheftel, C. Eriksson, M. Jul, H. Leniger, P. Linko, G. Varela, G. Vos) Elsevier Applied Science Publisher, London, 155-161.

Van Hoan N., Mouquet-Rivier C., Treche S., 2010. Effects of starch, lipid and moisture contents on extrusion behaviour and extrudate characteristics of rice-based blends prepared with a very-lowcost extruder. J. Food Process. Eng., 33(3), 519-539, doi:10.1111/j.1745-4530.2008.00288.x

Wójtowicz A., Mitrus M., Oniszczuk T., Mościcki L., Kręcisz M., Oniszczuk A., 2015. Selected physical properties, texture and sensory characteristics of extruded breakfast cereals based on wholegrain wheat flour. Agric. Agric. Sci. Procedia, 7, 301-308, doi:10.1016/j.aaspro.2015.12.051 


\title{
BADANIA PROCESU EKSTRUZJI DWUŚLIMAKOWEJ MIESZANEK ROŚLINNO-MIESNYCH PRZEZNACZONYCH DLA ZWIERZĄT DOMOWYCH
}

\author{
Aldona Sobota, Piotr Zarzycki, Emilia Sykut-Domańska, Anna Wirkijowska,
} Zbigniew Rzedzicki, Agnieszka Pawlas

Zakład Inżynierii i Technologii Zbóż

Katedra Technologii Surowców Pochodzenia Roślinnego i Gastronomii

Uniwersytet Przyrodniczy w Lublinie

ul. Skromna 8, 20-704 Lublin

e-mail: piotr.zarzycki@up.lublin.pl

Streszczenie. Przeprowadzono badania nad możliwością wykorzystania technologii ekstruzji „suchej” do przetwarzania mieszanek roślinno-mięsnych. Określono wpływ udziału komponentów mięsnych (miazga mięsno-kostna), roślin strączkowych (nasiona bobiku), rozdrobnionego ziarna pszenicy oraz temperatury wytłaczania na przebieg procesu, właściwości fizyko-chemiczne oraz mikrostrukturę ekstrudatów. Wykazano, że zastosowanie ekstrudera dwuślimakowego umożliwia przetwarzanie mieszanek z udziałem miazgi mięsno-kostnej dochodzącej do 30\%. Zwiększenie udziału komponentu mięsnego powoduje obniżenie gęstości właściwej i rozpuszczalności suchej masy (WSI) ekstrudatów. Odnotowano także, wzrost zawartości białka, tłuszczu i popiołu w ekstrudatach. Podniesienie temperatury wytłaczania z 130 do $250^{\circ} \mathrm{C}$ wpłynęło na wzrost stopnia ekspandowania i udarności oraz obniżenie gęstości właściwej ekstrudatów. Jednocześnie mikrostruktura ekstrudatów z formy zwięzłej i zbitej przeszła w formę bardziej wyekspandowaną i porowatą.

Słowa kluczowe: ekstruzja, bobik, miazga mięsno-kostna, karma, pszenica 